\title{
Navolging van Jesus, mimesis en 1 Johannes
}

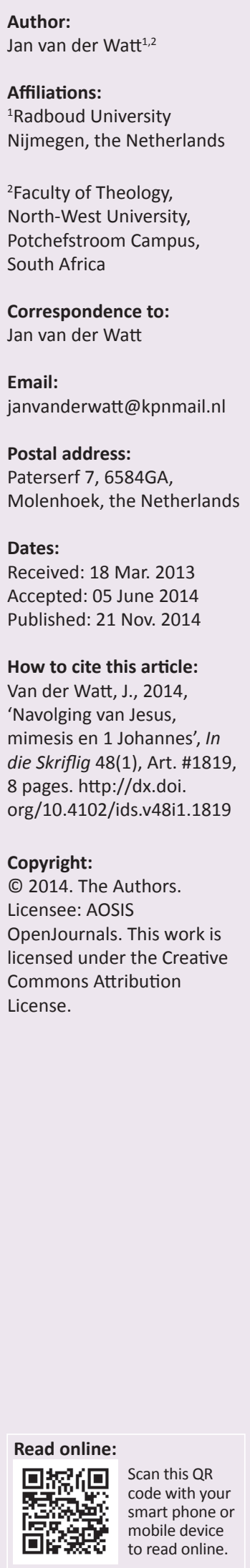

Hierdie artikel ondersoek die moontlike aanwending van mimesis in 1 Johannes. Daar word 'n oorsig gegee oor die gebruik van mimesis in die antieke tyd en sekere relevante eienskappe van mimesis word uitgelig. Die verwysings in 1 Johannes na gelowiges wat soos Jesus moet wees of optree, word nagegaan en in die lig van die eienskappe van die antieke gebruik van mimesis geïnterpreteer.

Imitating Jesus, mimesis and $1 \mathrm{John}$. The possible use of mimesis in $1 \mathrm{John}$ is investigated in this article. An overview is given of the use of mimesis in ancient times and certain characteristics are identified. The references in 1 John to believers that must be or act like Jesus are identified and interpreted in the light of the ancient use of mimesis.

\section{Inleiding}

Jesus maak die Vader bekend (Joh 1:18) en as iemand Jesus sien, het die persoon die Vader gesien (Joh 14:9). Op hierdie manier word die transendentale realiteit in die aardse werklikheid geïnkarneer. Die manier waarop Jesus hierdie transendentale realiteit in die wêreld bemiddel, is deur sy teenwoordigheid in woorde en in dade. In Johannes 13:15 en 34 verbind Jesus sy openbarende woorde en dade aan sy dissipels deur te sê: 'Ek het vir julle 'n voorbeeld gestel, en soos Ek vir julle gedoen het, moet julle ook doen' en 'Soos Ek julle liefhet, moet julle mekaar ook liefhê. ${ }^{1}$ In Johannes 14:12 sê Hy: 'Wie in My glo, sal ook die dinge doen wat Ek doen; en hy sal nog groter dinge as dit doen.' Die idee van die navolging van Jesus as die basis vir korrekte optrede word hier duidelik geillustreer. Op hierdie manier word die transendente realiteit ook eties in hierdie wêreld gestalte gegee. Die idee dat iemand 'n persoon of sy gedrag en houding navolg $\left(\right.$ mimesis $\left.^{2}\right)$, veral met betrekking tot etiese gedrag, was algemeen in die antieke Grieks-Romeinse en selfs die Hellenisties-Joodse kontekste bekend.

\section{'n Kort oorsig oor mimesis in die antieke tye}

In die antieke tye is mimesis of navolging as 'n sosiaal-aanvaarde praktyk gesien (vgl. Auerbach 1994; Melberg 1995). Die praktyk van mimesis is nie tot 'n enkele sfeer van die lewe beperk nie, maar is wyd op verskeie velde van die werklikheid toegepas (vgl. Castelli 1991:14). Harrison (2013) merk op:

Morrison observes that the Greek philosophers had nominated three areas in which mimesis occurred, namely, (a) the realm of nature; (b) the realm of art; and (c) the realm of moral reproduction. ${ }^{3}$ (p. 215)

Plato (vierde eeu v.C.) was die eerste om oor die rol van mimesis te besin, veral in kuns (Nightingale 2006:42). Hy het geredeneer dat letterkunde en kuns daarop gemik is om mense te beïnvloed en hulle so aan te moedig om die voorbeeld daarvan na te volg (vgl. Plato Rep. 595a-598d). Hy het homself egter nie tot kuns beperk nie, maar het die belang van nabootsing op 'n etiese vlak ook beklemtoon (Plato Grg. 511a). Aristoteles het nie met sy leermeester saamgestem nie en het gekonstateer dat letterkunde en kuns met die fiktiewe wêreld te doen het. Dit moes nie verpolitiseer word nie maar tot die sfeer van estetika beperk word (Nightingale 2006:40-46). Letterkunde en kuns hoef dus nie nageboots te word nie (Aristoteles Poet. hfst 4; 6.1450a; 9.1451b; 23.1459a; 24.1460b; 26.1461b-1462b). Hoe dit ook al sy, die verskynsel van nabootsing was 'n wesenlike deel van die antieke wêreld se sosiale gedragskonvensies.

\footnotetext{
1.Aanhalings kom uit die Bybel (nuwe vertaling 1998).

2.Die woord mimesis word slegs een keer in die Johannese geskrifte gebruik. In 3 Johannes 11 word dit in die gebruiklike sin aangewend van die goeie wat nagevolg moet word eerder as die bose. Buiten hierdie geval, kom die woord nie voor nie, alhoewel die idee of van die goeie wat nagevolg moet word eerder as die bose. Buiten hierdie geval, kom die woord nie voor nie, alhoewel die idee of
konsep nie afwesig is nie. Dit word ook op verskillende wyses in Johannes gemotiveer. Die term word in hierdie artikel in sy tegniese konsep nie afwesig
betekenis gebruik.
}

3.Castelli (1991:14) verwys ook na die sfere van godsdiens, politiek, opvoeding en retoriek. 
Dit is belangrik om daarop te let dat mimesis nie primêr 'n enkelvoudige teorie is nie. ' $n$ Mens kan byvoorbeeld nie van die 'teorie of model van mimesis' praat nie (hoewel dit tog in sommige gevalle gedoen word). Dit motiveer en beskryf egter 'n gedragshouding: 'a fundamental outlook shared by most authors, philosophers and ancient educated audiences in the classical period' (Sörbom 2002:19). Alhoewel die terme, $\mu \mu \eta \tau$ '́ [imiteerder] of $\mu$ í $\mu \mu \alpha$ (beeld) primêr is, druk ander terme ook 'n soortgelyke idee uit, byvoorbeeld ító $\delta \varepsilon 1 \gamma \mu \alpha$

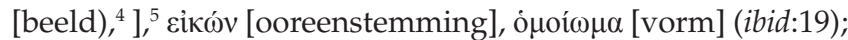
dieselfde geld van vergelykende terme soos $\kappa \alpha \theta \dot{\omega}$ [net soos] of $\dot{\omega} \varsigma$ [soos] of konstruksies soos 'as ... dan'. Die konsep van navolging en nie die spesifieke woord nie, moet ' $n$ mens in die bepaling van die aanwesigheid van hierdie verskynsel in 'n teks lei. ${ }^{6}$ As houding het mimesis in verskillende sosiale kontekste gefunksioneer, byvoorbeeld binne 'n familiekonteks, 'n navolgers- of 'n vriendskapskonteks en so meer. Die rede vir die mimetiese verwagtings kan dus ook vanuit die sosiale dinamiek gemotiveer word.

Castelli (1991:16) maak verskeie nuttige gevolgtrekkings uit sy breedvoerige analises oor die mimesis-konsep wat as riglyne vir die identifisering van die verskynsel kan dien. Castelli merk wel op dat sy gevolgtrekkings op 'n hoër vlak van abstraksie beoordeel moet word. Hy konkludeer:

1. 'Mimesis is always articulated as a hierarchical relationship, whereby the "copy" is but a derivation of the "model" and cannot aspire to the privileged status of the "model".'

2. Mimesis versterk die gedagte van eenvormigheid teenoor verskil. Sekere konseptuele vergelykings gaan hiermee saam: eenheid en harmonie word met eenvormigheid geassosieer, terwyl verskil weer aan eienskappe van diffusie, wanorde en onmin toegeskryf kan word.

3. Die konsep van die gesag van die model teenoor die kopie speel ' $n$ fundamentele rol in die mimetiese verhouding.

4. 'n Vierde aspek, verwant aan bogenoemde, is dat mimesis altyd asimmetries funksioneer, 'for imitation does not involve both elements moving simultaneously toward similarity, but rather one element being fixed and the other transforming itself or being transformed into an approximation of the first' (Castelli 1991:21). Castelli vervolg:

It is the struggle to write the identity of the model onto the copy. Further, imitation implies, then, a critical relationship of power, insofar as the model represents the standard toward which its copies move. The model sets the terms of the relationship, which is both hierarchical and asymmetrical. (bl. 22)

Hoewel mimesis op verskillende lewensterreine teenwoordig is, is die interesse hier uiteraard veral in die idee van morele

4.Navorsers soos Mitchell (1992:39-60) fokus hoofsaaklik op Paulus en verwys na die retoriese konvensies van exempla wat in voorbedagte argumentasie gebruik word en wat in gedagte gehou moet word wanneer oor navolging gepraat word. Plutarch (Life of Pericles $1.4 ; 2.4$ ) verskaf byvoorbeeld morele exempla vir die mense wat in sy dag die leiding bied.

5.van exempla wat in voorbedagte argumentasie gebruik word en wat in gedagte gehou moet word wanneer oor navolging gepraat word. Plutarch (Life of Pericles $1.4 ; 2.4$ ) verskaf byvoorbeeld morele exempla vir die mense wat in sy dag die leiding bied.

6.Betz (1967:3) argumenteer ook dat daar nie 'n filosofiese kontinuïteit tussen die Grieks-Romeinse en die Christelike gebruik van navolging is nie, maar eerder ' $n$ teologiese kontinuïteit. Dit beweeg van die letterlike na die konseptuele vlak. reproduksie. ${ }^{7}$ In hierdie verband merk Harrison (2013:223) op dat die voorbeelde van voorvaderlike of persoonlike deug as modelle vir navolging deur toekomstige geslagte gedien het en:

... the literary comparison of famous Greeks and Romans in the writings of Plutarch, Valerius Maximus and the anonymous De Viris Illustribus ${ }^{8}$ serve the conservative function of either maintaining the ancient ethical tradition or reinforcing socially acceptable paradigms of leadership of past and future generations. ${ }^{9}$

In 'n inskripsie van Antiochus I van Kommagene (OGIS 383, eerste eeu v.C.) stel Antiochus versoening met die gode afhanklik van die mimetiese etos van sy afstammelinge: 'I expect them (his children) to imitate this fine example and ever increase the family honours that are part of their family heritage...'.

Daar was 'n verwagting dat die waardes in die dade van die betrokke persoon tot uitdrukking sou kom, wat impliseer dat woorde en dade moes ooreenstem. Die volgende vermelding dien as voorbeeld ten opsigte van Zeno in 'n Ateense dekreet $(261 / 260$ v.C.) waarin hy vereer word (aangehaal deur Diogenes Laertius 7.10-12): '... having offered to all as example his own life, which was in agreement with the theories he professed $\ldots .{ }^{\prime}{ }^{10}$ Dit herroep vroeëre filosofiese debatte (so ver terug as die Sofiste en Aristoteles) wat vra of 'n deugsame man inderdaad teen sy eie deug in kan optree. Volgens Quintilianus (Inst 12.2.29-30) behoort hierdie voorbeelde van deugsame mense in woorde en dade bespreek en bepeins te word:

It is still more important that we should know and ponder continually all the noblest sayings and deeds that have been handed down to us from ancient times ... Who will teach courage, justice, loyalty, self-control, simplicity and contempt of grief better than men like ... ${ }^{11}$

Harrison (2013) beweer ook dat hierdie voorbeelde, veral in tekste oor belangrike persone wat nagevolg moet word, nie oor individuele deugde handel nie, maar kollektief beskou moet word. Die afwesigheid van spesifieke morele kommentaar in baie gevalle laat individue toe om hulle eie gevolgtrekkings te maak. Harrison konkludeer:

7 .'The concept of mimesis, to copy a pattern or an example, strikes deeply into the Greek tradition of philosophy, education, and ethical teaching' (Mack 1995:146).

8.Die anonieme De Viris Illustribus bevat 77 biografiese sketse, 'exempla ... designed for the posterity ...' (Harrison 2013:242). Waar die taal van navolging gebruik word, hou dit verband met 'the maintenance of the cult and ancestral piety' (ibid:242).

9.Cicero (Rab. Post 1.2) merk op: '... it is almost an instinct in the human race that members of a family which has won credit in some particular line ardently pursue distinction, seeing that the virtues of their fathers are perpetuated by speech and recollection of the world ...' (vgl. ook Cicero Cael 30.72; Div Caec 8.25; Deiot 10.26, 28).

10. Hierdie voorbeeld kom van Harrington (2013:235) - hy bied ook ander voorbeelde aan.

11.Hier volg sommige opmerkings wat die belang van mimesis in die antieke tyd beklemtoon: Cicero (Sest 64.136): 'Ek moedig jou aan om die voorbeeld van jou voorouers te volg'. Tacitus (Hist 2.68) merk op:

Behou en bewaar, Dienspligtige Vaders, ' $n$ man van sulke goeie raad, sodat elke geslag met sy leermeester toegerus kan wees, en dat ons jong manne Regulus kan naboots, soos ons ou manne Marcellus and Crispus nageboots het.

Tacitus (Ann 3.55): 'ons eie tyd het talle uitstekende voorbeelde van uitmuntendheid en kultuur vir die nageslag opgelewer wat die nageslag kan naboots'. Valerius Maximus (Facta et Dicta Memorabilia - eerste eeu n.C.) verskaf ook voorbeelde Maximus (Facta et Dicta Memorabilia - eerste eeu n.C.) verskaf ook voorbeelde
(exempla) wat oor deug en ondeug handel, asook oor godsdienstige praktyke en antieke gebruike. 
In sum, the transformation envisaged for such new generations in De Viris Illustribus consisted in conformity to an idealized past and the reinvigoration of Rome's future leadership through a new commitment to its republican legacy. (pp. 242-243)

Twee punte is belangrik, naamlik dat daar met groepe en nie individue nie gepraat word (hoewel groepe uit individue bestaan en daar dus ook met individue gepraat word, maar dan as onderdeel van die groep); en dat individuele toepassings dikwels nie in detail aangebied word nie. Dit lei natuurlik daartoe dat die groep hulle eie etiese gevolgtrekkings moet maak. Hierdie gevolgtrekkings moes dan op die algemene beskrywings van deugde gebaseer wees. 'n Bepaalde siening van die wêreld wat 'n spesifieke stel waardes handhaaf, word hierdeur as normatief gestel. Die stel waardes het waardes uit die tradisie weerspieël, selfs so ver terug as Homeros (Nightingale 2006:37-38). Dit is as navolgenswaardig voorgehou indien 'n mens binne daardie tradisie wou staan.

Hieruit volg dat mimesis nie bloot 'n meganiese proses is waarvolgens iemand eenvoudig iemand anders naboots nie. In hierdie verband moet van twee punte kennis geneem word:

- Mack (1995:146) wys daarop dat mimesis 'n dieper betrokkenheid as net blote nabootsing veronderstel, want dit wat nageboots moet word, verteenwoodig die 'structure, character and the very being of things ... To imitate the pattern of an example meant to become like it, to share its character and meaning. ${ }^{12}$ Daar is dus nie sprake van meganiese nabootsing nie, maar eerder die nabootsing van die karakter, denke en die gesindheid van die model. Dit gaan dus by mimesis om baie meer as die blote meganiese navolging van aksies.

- Omdat die proses van mimesis nie meganies is nie, beteken dit dat albei 'n element van behoud sowel as 'n kreatiewe inkleding deel van die proses van navolging gemaak het. Brodie (2004:4) verbind die elemente van bewaring en kreatiwiteit wanneer hy sê: 'What was not acceptable was sheer invention, the fabrication of plots or myths that were unrelated to the common traditions. One had to show solid roots'. ${ }^{13}$ Die idee van kreatiwiteit binne die konteks van behoud en bewaring was deel van die wyse waarop na navolging gekyk is.

Met verwysing na Plato se standpunt, skryf Nightingale (2006:42):

The members of the audience ... adopt the values set forth by the literary text and endeavour to enact these in their actions. When they read or view textual mimesis, then, people are led to engage in mimetic behaviour in life. Plato is not suggesting, of course, that a person who reads the Iliad will rush out and strap on his

12.Volgens die antieke en veral die Platoniese perspektief is persepsie 'n soort indruk of proses waarin 'individual objects deliver their individual shapes and qualities,
but not their matter, to the mind' (Sörbom 2002:22). 'n Voorwerp soos 'n prent of beeldhouwerk kan nie al die eienskappe van die ware voorwerp verteenwoordig nie, maar is slegs 'n verstandelike afbeelding van die oorspronklike. Die persoon reageer ooreenkomstig hierdie verstandelike afbeelding, onder andere ook deur 'n eie kreatiewe invulling.

13.Alhoewel hy dit oor tekste sê, is dit ook van toepassing op dade. sword; rather, the reader or viewer internalizes an entire value system, adopting a whole set of ideas about what constitutes a good person and a good life.

Die ideaal was nie net om bloot jou voorouers na te volg nie, maar om hulle te oortref om sodoende die roem van die familie te verhoog. ${ }^{14}$ Albei hierdie punte onderskei navolging as ' $n$ dinamiese proses van wettisisme wat meer meganies van aard is.

'n Verdere punt van belang is Nightingale (2006:42-43) se verduideliking van hoe Plato meen mimesis funksioneer wanneer iemand 'n teks lees. Lesers word aangemoedig om met karakters te identifiseer, of om te reageer asof hulle regte mense is. In die daad van identifikasie assimileer lesers hulleself aan die hand van die karakter. Dit lei die lesers om 'n sekere stel waardes te bevestig (of te verwerp): 'As a result we take the voices and ideas of other people into our minds: we substitute other people's thoughts and feelings for our own.' In die evangelie en briewe van Johannes, wat performatiewe tekste verteenwoordig (Van der Watt 2010:141-147, 167), behoort nie net die karakters in die verhaal Jesus na te volg nie, maar ook die lesers wat in die teks met die voorstelling van Jesus gekonfronteer word.

Alhoewel die konsep van mimesis uit 'n Hellenistiese agtergrond kom (Betz 1967:3), is die idee van navolging op die morele vlak nie tot die Grieks-Romeinse kontekste beperk nie. Dit word ook in latere Joodse en Christelike kontekste aangetref. In die Ou-Testamentiese tradisie bestaan min getuienis dat hierdie stelsel sterk funksioneer in die sin dat God nagevolg moes word. Sy wet moes eerder as normatiewe riglyn gehoorsaam word. Die verskynsel is eers later onder Hellenistiese invloed meer binne Joodse kontekste opgeneem. In die LXX (2 Makk 6:28-31; vgl. ook 4 Makk 17:22-23 ${ }^{15}$ ) word die verhaal van Eleásar byvoorbeeld vertel. Die owerhede moedig hom aan om sy eie lewe te red deur sy geloof te verloën, deur kos van die heidense altaar te eet. Hy weier om dit doen en sê dan:

Ek sou nou miskien die straf van mense kon vryspring, maar of ek nou lewe of dood is, ek sal nooit uit die hande van die Almagtige kan ontsnap nie. Dus, die waardige ding vir 'n persoon op my ouderdom om te doen sou wees om nou dapper te sterf. So sal ek vir die jongmans 'n edel voorbeeld nalaat, naamlik hoe om uit vrye wil en op 'n edel manier vir die gerespekteerde en heilige wette te sterf. (2 Makk 6:26-28)

Die verteller van 2 Makkabeërs (6:31) se opmerking plaas hierdie woorde van Eleásar in perspektief: 'So is hy toe dood. Deur sy dood het hy 'n voorbeeld van edelheid en durf nagelaat, 'n monument van dapperheid, nie alleen vir die jongmans nie, maar vir die hele volk.' Josephus (Ant. 12.203)

14. Harrison (2013:223-224) gebruik die Skipioniese grafinskripsies as voorbeelde om te illustreer hoe prominent die begeerte was om die voorouers in gedrag na te boots sodat ' $t$ he nobilitas of the family is rendered even more nouers in gedrag na te boots sodat the nobilitas of the family is rendered even more noble and virtuous'. Van elke adellike is verwag om dieselfde deugde as sy voorouers uit te leef of hulle selfs te of a model. It is an expression of obedience' (aangehaal deur Castelli 1991:26-27).

15. Hier vertel Antiochus aan sy soldate dat die moed van die moeder met haar sewe seuns as voorbeeld vir hulle moes dien. 
beklemtoon ook dat die voorbeeld van die vader nagevolg moet word - wat 'n mimetiese houding veronderstel.

In die Nuwe Testament is daar ook duidelike tekens van die praktyk van mimesis wat waarskynlik aan die Hellenistiese invloede te danke is. Geleerdes het aan hierdie praktyk begin aandag gee, veral in die Pauliniese briewe ${ }^{16}$ wat na die navolging van Paulus self, Christus, God of ander kerke verwys (vgl. 1 Kor 4:16; 11:1; Fil 3:17; Ef 5:1; 1 Tess 1:6; 2:14; 2 Tess 3:7). In Mattheus 5:48, Lukas 6:36, Hebreërs 6:12 en Jakobus 5:10-11 kom die idee ook voor en dit word ook in die kerkvaders voortgesit (vgl. 1 Klem 17:1; MPol 1:2l 17:3; IPhld 7:2; Dg 10:4b, 6; IEph 1:1) .

Binne die breë raamwerk wat die teenwoordigheid en selfs belangrikheid van die konsep van navolging of mimesis in 'n wye spektrum van die samelewing geillustreer het, kan nou oorweeg word of en in watter mate hierdie houding in 1 Johannes weerspieël word. ${ }^{17}$

\section{Om God en Jesus as gesaghebbende voorbeeld in 1 Johannes na te volg ${ }^{18}$}

Die etiek in 1 Johannes vind uitdrukking in verhoudings soos onder andere blyk uit die begrippe gemeenskap (koinōnia) of filiale taal (Vader, Seun, broers, geboorte, lewe, ens.) wat veelvoudig in Johannes voorkom (vgl. Van der Watt 2012a). 'n Belangrike wyse waarop die verhoudingsetiek in 1 Johannes ontwikkel word, is deur middel van die etiese voorbeeld van Jesus wat nagevolg moet word. Om die voorbeeld van Jesus na te volg, vorm inderdaad 'n basiskenmerk van die etiek van 1 Johannes. 'n Standaard is deur God en Jesus gestel en gelowiges moes dit navolg. Uitdrukkings soos soortgelyk aan,

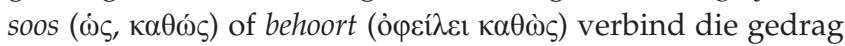
van Jesus funksioneel, maar hiërargies-outoritatief met dié van die gelowiges. Voorbeelde van Jesus wat nagevolg moet word, is gevarieerd. In 1 Johannes 2:6 word 'n algemene uitdrukking ten opsigte van die gedrag van gelowiges aangetref; dan volg twee uitdrukkings (2:29 of 3:7 en 3:3 rakende geregtigheid en reinheid) wat verband hou met identiteit; die beskrywing in 4:11 (om lief te hê) handel oor optrede wat op gesindheid gebaseer is - in 3:16 word liefde nouer gedefinieer in terme van die fisiese daad van sterwe.

\section{Om op dieselfde wyse as Jesus te leef (te wandel)}

In 1 Johannes 2:6 word die voorbeeld van Jesus se optrede as 'n model deontologies verbind aan die gedrag van die gelowiges.

16.Vergelyk byvoorbeeld Bartchy (2003); Belleville (1996); Betz (1967); Castelli (1991); Clarke (1998); De Boer (1962); Dodd (1999); Fiore (1986); Harrison (2013); Hawthorne (1996); Mitchell (1992); Reinhartz (1987); Schulz (1962).

17.'n Kort nota oor die manier waarop die sosiale materiaal hier gebruik word, is nodig. Dit word nie gesuggereer dat bewys kan word dat Johannes spesifiek by 'n sosiale struktuur aangesluit het nie. Wat betoog word, is dat in die teks van 1 Johannes ooreenstemmende patrone gevind word wat in die wetenskap as eienskappe van mimesis geïdentifiseer is. Die betoog is nie hoe Johannes daaraan eienskappe van mimesis geidentifiseer is. Die betoog is nie hoe Johannes daaraan gekom het nie, maar wel
geïdentifiseer kan word.

18. Die volgende inligting vorm deel van ' $n$ groter projek oor die etiek van Johannes en soortgelyke materiaal kan ook in publikasies van Van der Watt gevind word, omdat soortgelyke materiaal kan ook in publikasies van Van der Watt gevind word, omdat
dit ' $n$ sentrale deel van die etiek van Johannes vorm. Die materiaal word hier in dit ' $n$ sentrale deel van die etiek van Johann
terme van die antieke mimesis ontwikkel.
Hierdie uitspraak situeer die etiek binne 'n intieme en aktiewe verhouding tussen Jesus en die gelowiges (vgl. Brown 1986:263; Lieu 2008:74): 'Wie beweer dat hy in Hom bly, behoort self ook te lewe soos Jesus gelewe het'

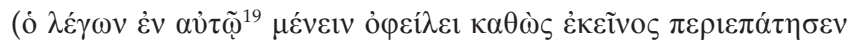

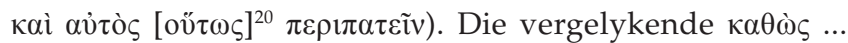
[oṽ $\omega \varsigma$ ] verbind die gedrag van die model, Jesus, aan hulle wat in Hom bly (die kopieerders). Die verwagting van mimesis is duidelik, aangesien daar hiëragie, outoriteit stabiliteit en eenvormigheid aanwesig is.

Die woord $\pi \varepsilon \rho \iota \pi \alpha \varepsilon \dot{\epsilon} \omega$ [stap] wat in hierdie vers gebruik word, verwys na algemene gedrag (beweeg, rondloop) in die alledaagse lewe. ${ }^{21}$ Gelowiges moet dus hulle alledaagse gedrag nadenkend sodanig struktureer dat hulle tussen ander mense rondbeweeg soos Jesus dit gedoen het. ${ }^{22}$ Wat tipeer die rondloop $(\pi \varepsilon \rho \iota \pi \alpha \varepsilon \dot{\varepsilon} \omega)$ van Jesus sodat gelowiges verplig ${ }^{23}$ is om dit na te volg? In 1 Johannes is daar oorvloedige verwysings na dit wat die aangesprokenes geweet of al gehoor het; ${ }^{24}$ hulle het met ander woorde deel aan 'n bekende en lewendige Johannese tradisie. Hierdie tradisie gaan terug na Jesus self (1 Joh 1:1-4). Dit is dus van die aangesprokenes verwag dat hulle sou geweet het hoe Jesus opgetree het. Die beste aanname oor die oorsprong van hierdie kennis is dat dit voortvloei uit die Johannese tradisie wat in die Johannese groep vergestalt is. Dit word onder andere ook, maar waarskynlik nie uitsluitlik nie, in die Johannesevangelie uitgedruk waar Jesus se voorbeeld en gedrag hoofsaaklik in terme van onbeperkte liefde gedefinieer word (Joh 13:34-35). Liefde vorm ook die belangrikste etiese lyn in 1 Johannes (Van der Watt 2012b).

Is daar enige aanduiding in die gedeelte waarom daar verwag is dat ' $n$ persoon soos Jesus moes optree, met ander woorde, waarom 'n mimetiese houding verwag is? Gedrag word in die konteks met ' $n$ verwysing na Jesus se gebooie

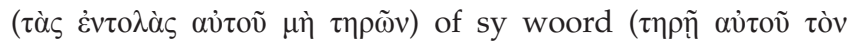
$\lambda$ óyov) gekwalifiseer, inter alia gemotiveer deur die feit dat gelowiges God ${ }^{25}$ ken. God se gebooie en woord (openbaring)

19. Die verwysing na $x v$ avo $\tilde{\omega}$ is heel waarskynlik na God, maar implisiet ook na Jesus (vgl. Smalley 2002:50).

20.Metzger (1994:639-640) maak die volgende evaluasie: 'The external evidence

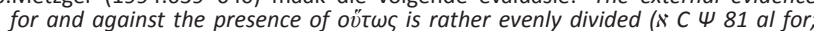
A B 33 2464* al against). From a transcriptional point of view, the word might have been accidentally omitted following aviós. On the other hand, it might

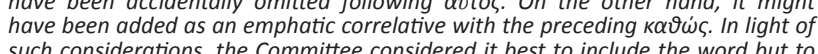
such considerations, the Committee considered it best to include the word but to enclose it within square brackets.' Brown (1986:262-263) en Lieu (2008:74) gee gedetailleerde beskrywings van die gebruik van die vergelykende partikel in die
evangelie en briewe van Johannes.

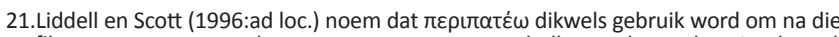
filosowe te verwys wat heen en weer stap wanneer hulle geredeneer het. Arndt et al. (2000) dui aan dat waar dit in die Nuwe Testament gebruik word, dit altyd 'more exactly defined' is. Die uitdrukking herinner aan soortgelyke gebruike in die Eerste Testament. Painter (2002:144) merk op dat Johannes die uitdrukking graag gebruik.

22.Smalley (2002:52) is van opinie: 'The particular aspect of obedience mentioned on this occasion is Christlikeness'.

23.Klauck (1991:118) praat van 'n Verpflichtung (vgl. Haas et al. 1972:43; Painter 2002:170).

24.Vergelyk onder andere 1 Johannes 2:13-14, 20-21; 3:1, 5, 6, 14-15; 4:7; 5:13, 18 , 19, 20; ensovoorts.

25.'n Kenmerk van 1 Johannes is dat daar in verskeie gevalle in die brief onsekerheid bestaan oor die refererent, byvoorbeeld of ' $n$ persoonlike voornaamwoord na Jesus of na sy Vader, God, verwys. 
is dus rigtinggewend vir gedrag. Die gesaghebbende of hiërargiese aard van die argumentasie is duidelik: gedrag in die groep (familie van God) word bepaal deur God wat sy gebooie deur Jesus (wat die gebooie self gehoorsaam het) aan die res van die groep deurgegee het. Op hulle beurt moet hulle dit ter wille van eenvormigheid gehoorsaam. Die gebooie vorm 'n stabiele punt van oriëntasie vir die gelowiges.

Wat bind hierdie mimetiese ketting saam? In die onmiddellike konteks word tipiese Johannese relasie-uitdrukkings aangetref, byvoorbeeld om God en Jesus te ken (ó $\lambda \dot{\varepsilon} \gamma \omega v$ ö $\tau$

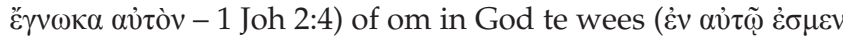
- 1 Joh 2:5. Vergelyk ook die uitdrukkings om in sy liefde en waarheid te wees -1 Joh 2:4-5). Die rede vir die mimesis is die intieme hiëragiese verhouding wat tussen die model (God en Jesus) en die kopieerder (die gelowiges) bestaan. In die direk voorafgaande verse (1 Joh 2:1) word daar na God as Vader verwys en wanneer daar verder oor die liefde gepraat word, word die term broeders gebruik (1 Joh 2:9), wat op filiale beeldspraak dui. Die intieme verhouding word sodoende met die sosiale realiteit van die familie in verband gebring. Binne hierdie sosiale en relasionele opset is mimesis te verwagte en te verstane. ${ }^{26}$

\section{Om regverdig te wees soos God en Jesus regverdig is}

Twee uitdrukkings moedig gelowiges aan om eties oor die eienskappe van Jesus te besin, naamlik om regverdig op te

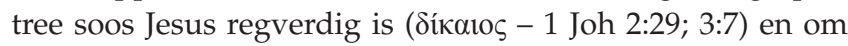

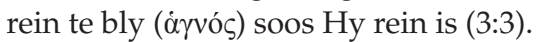

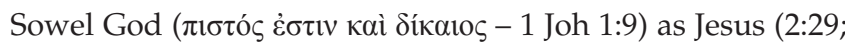
3:7) word in 1 Johannes as regverdig beskryf en die aard en karakter van wat regverdigheid behoort te wees, word aan hulle gemeet. In 1:9 en 2:1 word die regverdigheid van God en Jesus aan hulle optrede gekoppel, wat verband hou met die uitwissing van die sonde en van die gevolge daarvan (vgl. ook 3:7). In die lig hiervan lyk dit waarskynlik dat regverdigheid in 1 Johannes na dit verwys wat teenoor die sonde staan (Lieu 2008:118-119), naamlik daar waar sonde in persone asook in hulle optrede ontbreek (Brown 1986:209). Om regverdig te wees, ${ }^{27}$ verwys na optrede wat in ooreenstemming is met wat reg is volgens God se wil soos dit in Jesus geopenbaar is. In 2:29 word Jesus se regverdigheid en die regverdigheid van die gelowiges binne die filiale konteks verbind: 'As julle weet dat Hy regverdig is, weet julle ook dat elkeen wat die geregtigheid doen uit Hom gebore is'

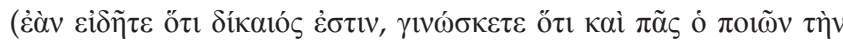

26.Brown (1986:285) sien die kern van hierdie vers daarin dat dit die feit onderstreep dat ' $n$ mens se 'bly in God of Jesus' nie van ' $n$ mens se daaglikse lewe geskei kan word nie. Akin (2001:95) volg Strecker en formuleer dit effen dogmaties: '... the indicative and the imperative of the Christian life are joined together as a cause and effect. This union occurs only to the degree that the soteriological significance of the death and resurrection of Jesus the Christ precedes the ethical imperative, so that the indicative of the Christ-event becomes the foundation for and the content of the imperative.' 'Dit is egter ' $n$ vraag of die gebruik van imperatiewe en indikatiewe enigsins geskikte analitiese kategorieë vir die Johannese literatuur vorm.'

27.Vir agtergrondinligting, vergelyk die volgende opmerking deur Smalley (2002:167): There is a clear OT background to the concept of acting 'righteously,' and being 'righteous' (סíkaloc). See Gen 18:23-26; Ps 1:6; Isa 60:21; Dan 12:3. In the NT this 'righteous' (סikatoc). See Gen 18:23-26; Ps 1:6; Isa 60:21; Dan 12:3. In the NT this
language is particularly associated with Paul (cf. Rom 1:17; 3:21-26; 5:1); but it is also found elsewhere (cf. Matt 23:28; Luke 18:14; 1 Pet 4:18; Rev 22:11).

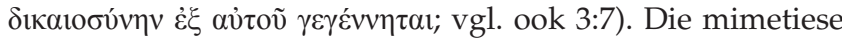
aard van die opdrag is dus ingebed in die feit dat gelowiges uit God gebore is. Binne die sosiale konvensies van daardie tyd was dit te verwagte dat 'n kind soos sy vader sou optree (vgl. Joh 8:38-41).

Hierdie interpretasie word in 1 Johannes 3:12 bevestig (Brown 1986:441-443). Regverdige dade word in die verhaal van die familielede, Kain en sy broer, met bose dade gekontrasteer

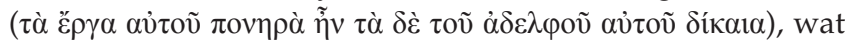
impliseer dat bose dade met die etiese verwagtings van wat goed is, bots. Die kontras tussen die bose en die goeie asook die verwagting dat die goeie mimeties (vgl. die gebruik van die woord $\mu \mu \mathrm{ov}$ ) nageboots word, word direk in 3 Johannes 11 geformuleer: 'moenie die slegte navolg nie, maar die goeie'

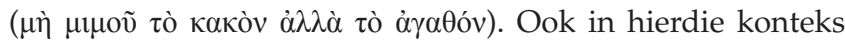
word die intieme verhouding met God, wat na die oorsprong teruggaan, beklemtoon ('hy wat die goeie doen is uit God; Hy wat die slegte doen het God nie gesien nie' - ó $\alpha \gamma \alpha \theta$ o $\pi$ oi $\tilde{v}$

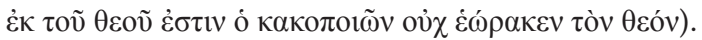

\section{Om rein soos Jesus te wees}

In 1 Johannes 3:3 word verklaar dat 'elkeen wat hierdie hoop in verband met Hom het, homself reinig ${ }^{28}$ soos daardie Een

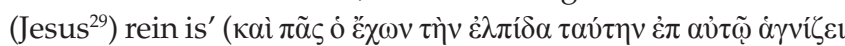

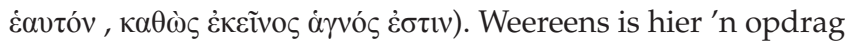
dat Jesus nagevolg moet word (Johnson 1993:69). Gelowiges moet hulleself reinig ${ }^{30}$ deur middel van positiewe en bewuste optrede volgens die voorbeeld wat Jesus gestel het. In hierdie sin moet hulle Jesus navolg.

Die woord reinheid (árvós) 'refers to cleanliness and holiness of life' wat kultiese of rituele ondertone het, alhoewel die woord ook leksikografies na morele gedrag kan verwys. ${ }^{31}$ Dit kan na sowel kwaliteit as die aksies verwys wat nodig is om daardie kwaliteit te bereik. In 1 Johannes 3:3 word die vereiste gestel teen die agtergrond van die eskatologiese verwagting van die toekomstige verskyning van Jesus. Dan sal gelowiges soos Hy wees (3:2), iets wat reeds moes begin het en steeds plaasvind. Gelowiges moet hulleself reinig soos Jesus rein is, om te word soos wat hulle gaan wees wanneer Hy geopenbaar gaan word. ${ }^{32}$ Die volgende vers bied 'n

28.Arndt et al. (2000:ad loc.) onderskei tussen drie moontlike gebruike: (i) om te suiwer en rein te maak sodat dit vir kultiese gebruik aanvaarbaar sal wees; (ii) om te sorg dat dit moreel rein sal wees; (iii) om iets in toewyding af te sonder. Die term te sorg dat dit in word slegs hier in die briewe gebruik en een keer in die evangelie (1 Joh 11:55) in die verwysing na die kultiese reiniging van die Jode. Haas et al. (1972:85) erken die onderskeie moontlike gebruike, maar kies vir die rituele betekenis; so ook Klauck
(1991:183) en Smalley (2002:149).

29. Haas et al. (1972:85) huldig die volgende mening: 'The pronoun he, lit. "that one," refers unequivocally to Christ'.

30.Die teenswoordige tyd fokus op die voortgaande aard van die aktiwiteit (Haas et al 1972:85; Johnson 1993:69).

31.Vergelyk Arndt et al. (2000:ad loc.) en Louw and Nida (1996:ad loc.). Painter (2002:222) meen daar is geen aanduiding van wat reinheid beteken nie. Hy beskou dit as ' $n$ rituele term alhoewel geen ritueel geïmpliseer word nie. Brown (1986:397-98) argumenteer vir' $n$ rituele gebruik in die sin dat Christene hulleself moet heilig sodat argumenteer vir ' $\mathrm{n}$ rituele gebruik in die sin dat Christene hulleself moet heilig sodat hulle die goddelike kan 'ontmoet'. Hulle doen dit deur die reinigende bloed van Jesus die morele gebruik van die woord nie misgekyk word nie.

32.Akin (2001:137) beklemtoon hier die verband tussen eskatologie en etiek: 'John joins his previous eschatological thoughts with a moral, practical conclusion. Being born of God creates a vibrant hope for the future, one that motivates pure living in everyday life'. 
raamwerk waarbinne die konteks van reinheid verstaan moet word - die persoon moet nie sondig nie, want sonde is gelykstaande aan wetteloosheid ( $\left.\dot{\alpha} v o \mu i^{\prime} \alpha\right)$. Diegene wat in Jesus glo, moet geen deel aan die sonde as eienskap van die duiwel, hê nie (3:5-6). Die motivering vir hierdie mimetiese gedrag van die gelowiges is ook in hierdie konteks direk met filiale relasies verbind (vgl. 3:1-3) - die Vader het hulle so lief dat hulle kinders van God genoem mag word; met 'n eskatologiese verwagting om te wees soos Jesus is.

\section{Om lief te hê soos God en Jesus liefgehad het}

Die laaste en duidelikste voorbeeld gaan oor die gelowige wat die liefde van God en Jesus mimeties moet navolg. God is die bron en oorsprong van liefde (1 Joh 4:7) en is inderdaad liefde $(4: 8,16)$. Hy het sy liefde konkreet getoon deur sy Seun na die wêreld te stuur (4:9-10) ... as dit is hoe God sy liefde aan ons bewys het, behoort ons mekaar en God ook lief te hê $(4: 11,21)$; meer nog, gelowiges moet liefhê omdat God hulle eerste liefgehad het (4:19). Poreusheid kenmerk die wyse waarop liefde van God deur Jesus na die gelowige vloei. Dit dring alle verhoudings binne en bepaal dit. Dit impliseer 'n ooreenkoms in die houding en uitdrukking tussen die Vader, die Seun en die gelowiges. Die poreusheid is mimeties van aard in dié sin dat die verhouding hiërargies en gesagvol is en na eenvormigheid met die Vader en die Seun streef as vaste oriënteringspunte (vgl. die kwaliteite van mimesis soos vroeër bespreek).

Die mimetiese aard van die liefde word die duidelikste in 1 Johannes 3:11-18 geillustreer. Die konteks reflekteer op 'n sekondêre vlak die konflik met die opponente. Die verskil tussen haat en liefde word geillustreer deur die verhaal van Kaïn wat sy broer doodmaak omdat sy dade sleg was (vgl. Smalley 2002:195). Mense wat daardie voorbeeld navolg deur soortgelyk op te tree, bevestig hulle verbondenheid aan Kaïn. Aan die ander kant, om iemand lief te hê (3:11), sal nie daartoe lei om iemand skade aan te doen nie, maar sal lewe bemiddel, selfs al moet die persoon in die proses sy eie lewe inboet (3:16). Dit is die aard van liefde.

Die aard van God se liefde is deur Jesus gefasiliteer - Hy lê sy lewe vir 'ons' af ('ons' = die outeur van die brief en sy

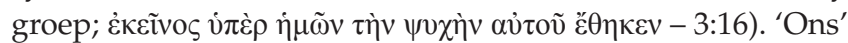
dade behoort (in die sin van 'n verpligting of plig - Brown 1986:449) dié van Jesus mimeties na te volg - 'ons' behoort ook ons lewe vir medegelowiges af te lê (Smalley 2002:244). Die liefde van God deur Jesus vorm duidelik die voorbeeld en norm vir die gedrag van die gelowiges. Die hiërargiese sowel as die gesagvolle aspek van mimesis tipeer hierdie uitspraak. Dit is die vaste oriënteringspunt waaraan elke gelowige sigself meet.

As voorbeeld van die wesenlike aard van die liefde lê Jesus sy lewe af deur sy dood aan die kruis (vgl. ook Joh $10: 11,15,17-18 ; 13: 37,38 ; 15: 38)$. Wat presies impliseer die feit dat van gelowiges verwag word om mimeties hierdie liefdesuitdrukking van Jesus na te volg? In 1 Johannes 3:17 word dit soos volg verduidelik: 'Wie aardse besittings het

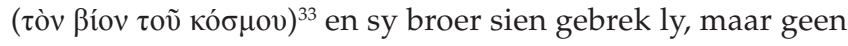
gevoel vir hom het nie - hoe kan die liefde van God in hom wees?' Hierdie retoriese vraag (vgl. Haas et al. 1972:101; Johnson 1993:160) beklemtoon die positiewe kant: Liefde vir God impliseer dat gelowiges hulle lewe vir medegelowiges behoort af te lê. Dit gebeur wanneer gelowiges ander broers en susters wat in nood verkeer, met deernis help. ${ }^{34} \mathrm{Op}$ hierdie manier fasiliteer hulle lewe in teenstelling met Kaï se optrede wat tot die dood lei. As hulle dit nie doen nie, ontstaan die vraag hoe die liefde van God dan in 'ons' kan

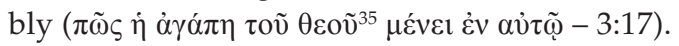

Hierdie beskrywing bied 'n illustrasie van wat dit beteken het om iemand in die antieke tye na te volg (mimiek). Om jou lewe vir 'n ander mens te gee, het in die geval van Jesus vereis dat Hy aan die kruis gesterf het; van gelowiges vereis dit dat hulle met ander deel wat daardie mense vir hulle oorlewing nodig het. Dieselfde kwaliteit liefde wat Jesus gedemonstreer het, word deur sy volgelinge nagevolg, hoewel hulle konkrete dade verskil. Navolging is inderdaad nie tot die fotokopiëring van konkrete dade beperk nie, maar gee ook uitdrukking aan die wese en karakter van dit wat nageboots word.

Die basiese vereiste van liefde is duidelik: volgelinge van Jesus behoort die lewe van die broers in nood op praktiese maniere te verbeter, selfs al mag dit ook offers van die navolgers van Jesus vra, dalk tot op die punt waar hulle hul lewe moet aflê. Nie 'n lys nie, maar 'n relasionele, interpretatiewe en kognitiewe benadering vorm hier die middelpunt van Johannes se etiese program. Deur bewus te wees van wat mimesis in die algemeen behels, sensiteer ons om op hierdie manier eties te kan dink.

Indien bogenoemde wel die geval is, word die vraag na watter konkrete dade (bv. by wyse van deugdelyste oor die huwelik, die staat, die ekonomie, ens.) Johannes voorstaan, irrelevant. Die klem van die vrae lê egter verkeerd. Die gelowiges moet nie enkele dade nie, maar wel houding en inbors navolg en dit in ooreenstemmende dade tot uitdrukking bring. Wat veronderstel word, is meer 'n beginsel of 'n waardegedrewe etiese houding. Met ander woorde, daardie dade wat die houding van liefde - soos Jesus dit vergestalt - die beste in 'n betrokke situasie uitdruk, moet voorkeur kry. Om lyste van wat gedoen en nie gedoen moet word nie te verskaf, sou gelowiges se vryheid aan bande lê en dit is juis essensieel deel van die proses van mimesis.

33 Brown (1986.475) oorweeg kontekste soos die apokaliptiese laste wur, of die konflik met die opponente. Smalley (2002:196) redeneer dat hierdie verse nie

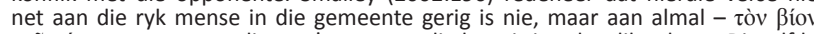

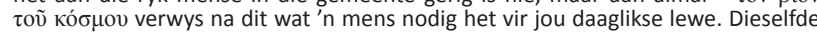
redenasie geld ten opsigte van Haas et al. (1972:91) en Painter (2002:242).

34. Brown (1986:474) beklemtoon die feit dat dit nie 'n nuwe opdrag is nie, maar deel van die Christendom se Joodse erfenis is - vergelyk Deuteronomium 15:7. Smalley (2002:197) is korrek wanneer hy daarop wys dat 'almsgiving, and the sharing of goods with those in need, was a feature of the early Christian Church inherited from Judaism'.

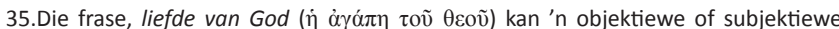
genitief wees, en kan as sodanig na die liefde wat God het, verwys, of die liefde wat 'n mens vir God het. Dit lyk asof albei geïmpliseer word en of op albei gesinspeel 'n mens vir God het. Dit lyk asof albei geïmpliseer word en of op albei gesinspeel laat blyk dat die aard van God se liefde eerder beklemtoon word. 
Die mimetiese aard blyk dus duidelik uit wat in hierdie gedeelte beskryf word. Dit is duidelik dat nie 'n konkrete optrede nie, maar die kwalitatiewe gehalte van die liefdesoptrede moet ooreenstem. Eties gesien moet die etos van die optrede van gelowiges ooreenstem met die etos van die lewegewende en liefdevolle God. Dit gaan nie oor 'n blote (presiese) afskrif of kopie van die optrede nie, maar om 'n kreatiewe uitdrukking van die karakter en aard van die model wat nagevolg moet word. 'n Kwalitatiewe interpretasie van God se liefde bepaal met ander woorde die konkrete uitdrukking van goddelike liefde deur gelowiges. Volgens die eis van mimesis is eenvormigheid van optrede nodig, maar nie 'fotokopiëring' nie.

In die algemeen gaan dit dus daaroor dat ware etiese optrede die skepping van lewe en nie die vernietiging daarvan nie nastreef - Jesus as die Gewer van lewe het lewe vir hierdie wêreld gebring. Deur sy dood aan die kruis het Jesus inter alia die ewige lewe vir gelowiges bemiddel. Dat iemand sy lewe vir iemand anders gee, was die toppunt van wat vir iemand anders gedoen kon word. Dit vereis 'n absolute en totale offer wat impliseer dat alles anders wat die persoon moontlik kan bied, per definisie daarby ingesluit is. Ekstra opdragte is nie nodig nie, want die hoofopdrag is inklusief. Die karakter en aard van so 'n voorbeeld sal die persone wat dit navolg, dwing om konsekwent te vra wat hulle vir die ander kan doen - verskillende situasies mag verskillende dade vereis, maar almal sal volgens die karakter van die goddelike liefde soos dit deur Jesus gedemonstreer is, wees. Die antropologiese grondtrek van hierdie uitsprake rus op die veronderstelling dat 'n persoon volgens sy identiteit sal optree. Hierdie aspek van antropologie staan al vanaf Sokrates in die sentrum van diskussie.

Daar moet egter op die breër konteks ook gewys word. In 1 Johannes 3 is die familie die basiese sosiale raamwerk waarbinne geargumenteer word (vgl. 1 Joh 3:1-2, 9-10; en die verhaal van Kaïn in 1 Joh 3:11-15). Mimesis word dus verwag omdat die aangesprokenes hulleself binne die familie bevind. Die veronderstelling is natuurlik dat binne die betrokke sosiale raamwerk mimeties opgetree moet word. Dit is moontlik omdat mimesis nie 'n sosiale model is nie, maar eerder 'n spesifieke gestruktureerde houding weerspieël.

\section{Enkele slotopmerkings}

In hierdie artikel is geargumenteer dat Johannes se aanbieding van die etiese materiaal ooreenstem met die antieke sosiale verskynsel van mimesis. Dit is aangetoon dat mimesis 'n houding is wat op sosiale verwagtings gebaseer was. Dit het verder geblyk dat in die Johannese opdrag dat gelowiges soos Jesus moet liefhê, mimetiese kwaliteite duidelik herkenbaar is, naamlik 'n hiërargiese en gesagvolle situasie wat na eenvormigheid streef. Jesus as model staan in 'n hiëragiese en outoritatiewe verhouding tot sy volgelinge as die vaste punt van oriëntering en die verwagting was dat eenvormigheid sal resulteer. Hierdie mimetiese gedrag is binne die raamwerk van die familie van God gekonkretiseer. Die rede waarom mimese nodig is, is omdat gelowiges kinders van God is. Dit geld ook vir ander aspekte soos reinheid en regverdigheid. Gelowiges moet inderdaad soos Jesus optree.

Mimesis blyk dus 'n basiese raamwerk te wees waarbinne die etiese dinamika in 1 Johannes aangebied word. Navolging of mimesis vorm die skakel tussen die voorbeelde wat God en Jesus stel en die gelowiges wat ook net soos Jesus geleef het, behoort te leef. Etiese gedrag behels inderdaad 'n gehoorsame verhoudingsoriëntasie (mimiek) teenoor Jesus en die Vader en nie die blote nakoming van 'n lys moets en moenies nie. Dit beteken dat die etos wat die algemeen aanvaarde gedrag binne die Christengemeenskap verteenwoordig, onder andere veronderstel dat die Vader en Jesus mimeties aan gelowiges, as kinders van God, gebind was. In die breër konteks gesien, is die basiese sosiale raamwerk van 1 Johannes 3 waarbinne geargumenteer word, die familie (vgl. 1 Joh 3:1-2, 9-10; die verhaal van Kaïn in 1 Joh 3:11-15). Mimesis word dus verwag, omdat die aangesprokenes hulleself binne die familie bevind. Die veronderstelling is dat binne die betrokke sosiale raamwerk mimeties opgetree moet word. Dit is moontlik omdat mimesis nie 'n sosiale model is nie, maar eerder 'n spesifieke gestruktureerde houding weerspieël.

\section{Erkenning Mededingende belange}

Die outeur verklaar dat hy geen finansiële of persoonlike verbintenis het met enige party wat hom nadelig kon beïnvloed het in die skryf van hierdie artikel nie.

\section{Literatuurverwysings}

Akin, D.L., 2001, 1, 2, 3 John, Broadman, Nashville.

Arndt, W., Danker, F.W. \& Bauer, W., 2000, A Greek-English lexicon of the New Testament and other early Christian literature, University of Chicago Press, Chicago.

Auerbach, E., 1994, Mimesis: Dargestellte Wirklichkeit in der abendländischen Literatur, 9, Druck, Francke, Bern.

Bartchy, S.S., 2003, 'Who should be called Father? Paul of Tarsus between the Jesus tradition and the Patria Potestas', Biblical Theology Bulletin 33(4), 135-147. http://dx.doi.org/10.1177/014610790303300403

Belleville, L.L., 1996, 'Imitate me, just as I imitate Christ: Discipleship in the Corinthian correspondence', in R.N. Longenecker (ed.), Patterns of discipleship in the New Testament, pp. 120-142, Eerdmans, Grand Rapids.

Betz, H.D., 1967, Nachfolge und Nachahmung Jesu Christi im Neuen Testament, Mohr \& Siebeck, Tübingen.

Brodie, T.L., 2004, The birthing of the New Testament: The intertextual development of the New Testament writings, Sheffield Phoenix Press, Sheffield.

Brown, R.E., 1986, The epistles of John, Doubleday, New York.

Castelli, E.A., 1991, Imitating Paul: A discourse of power, Westminster John Knox, Louisville.

Clarke, A.D., 1998, “'Be imitators of me": Paul's model of leadership', Tyndale Bulletin 49, 329-360.

De Boer, W.P., 1962, The imitation of Paul: An exegetical study, Kok, Kampen.

Dodd, B., 1999, Paul's paradigmatic 'I': Personal example as literary strategy, Sheffield Academic Press, Sheffield.

Fiore, B., 1986, The function of personal example in the socratic and pastoral epistles, Biblical Institute Press, Rome.

Haas, C., De Jonge, M. \& Swellengrebel, J.L., 1972, 1 John: A translator's handbook on the letters of John, United Bible Society, New York.

Harrison, J.R., 2013, 'The imitation of the "great man" in antiquity: Paul's inversion of a cultural icon', in S.E. Porter \& A.W. Pitts (eds.), Christian origins and GrecoRoman culture, pp. 213-254, Brill, Leiden.

Hawthorne, G.F., 1996, 'The imitation of Christ: Discipleship in Philippians', in R.N.

Johnson, T.F., 1993, 1, 2, and 3 John, Hendrickson, Peabody.

Klauck, H-J., 1991, Der erste Johannesbrief, Benziger Verlag, Zürich. 
Longenecker (ed.), Patterns of discipleship in the New Testament, pp. 163-179, Eerdmans, Grand Rapids.

Liddell, H.G. \& Scott, R., 1968, A Greek-English lexicon, Oxford University Press, Oxford Lieu, J.M., 2008, I, II, \&III John: A commentary, Westminster John Knox, Louisville.

Louw, J.P. \& Nida, E.A., 1996, Greek-English lexicon of the New Testament: Based on semantic domains, United Bible Societies, New York.

Mack, B.L., 1995, Who wrote the New Testament? The making of the Christian myth, HarperCollins, New York.

Melberg, A., 1995, Theories of mimesis, Cambridge University Press, Cambridge. http://dx.doi.org/10.1017/CBO9780511597732

Metzger, B.M., 1994, A textual commentary on the Greek New Testament, 2nd edn., United Bible Societies, London. (A companion volume to the United Bible Societies' Greek New Testament, 4th rev. edn).

Mitchell, M.M., 1992, Paul and the rhetoric of reconciliation, Westminster John Knox, Louisville.

Nightingale, A., 2006, 'Mimesis: Ancient Greek literary theory', in P. Waugh (ed.) Literary theory and criticism: An Oxford guide, pp. 37-47, Oxford University Press, Oxford.
Painter, J., 2002, 1, 2, and 3 John, Liturgical Press, Collegeville.

Reinhartz, A., 1987, 'On the meaning of the Pauline exhortation: "Mimetai Mou Ginesthe - Become imitators of me"', Studies in Religion 16, 393-403.

Schulz, A., 1962, Nachfolgen und Nachahmen: Studien über das Verhältnis der neutestamentlichen Jüngerschaft zur urchristlichen Vorbildethik, Kösel, München.

Smalley, S.S., 2002, 1, 2, 3 John, Word, Logos online, Waco.

Sörbom, G., 2002, 'The classic concept of mimesis', in P. Smith \& C. Wilde (eds.) A companion to art theory, pp. 19-28, Blackwell, Oxford. http://dx.doi. org/10.1002/9780470998434.ch2

Van der Watt, J.G., 2010, 'Ethics through the power of language', in R. Zimmermann \& J.G. van der Watt (eds.), Moral language in the New Testament, pp. 139-167, Mohr Siebeck, Tübingen.

Van der Watt, J.G., 2012a, 'Aspects of spirituality as it is reflected in 1 John', Studies in Spirituality 22, 89-108.

Van der Watt, J.G., 2012b, "'Working the works of God": Identity and behavior in the Gospel of John', in J.' Krans, B.J. Lietaert-Peerbolte, P-B. Smit \& A. Zwiep (eds.) Paul, John, and Apocalyptic eschatology, Festschrift M. de Boer, pp. 135-150, Brill, Leiden. 